\title{
BIOACCUMULATION OF HEAVY METALS BY THE WATER FERN AZOLLA PINNATA
}

\author{
ABD EL-ALL, AZZA A. M. ${ }^{1}$, ELHAM M. AREF ${ }^{1}$ AND \\ HANAN A. M. HASSANEIN ${ }^{2}$ \\ 1. Soils, Water and Environ. Res. Inst., ARC, Giza, Egypt. \\ 2. Animal Production Res. Inst., ARC, Giza, Egypt.
}

(Manuscript received 3 May 2011)

\begin{abstract}
Azolla pinnata aquatic fronds were tested for their ability to bioaccumulate heavy metals from Yoshida medium supplemented with different heavy metals, i.e. $\mathrm{Pb}^{+2}, \mathrm{Cd}^{+2}$ and $\mathrm{Cu}^{+2}$ at different concentrations $0.0,0.5,1.0,1.5$ and $2.0 \mathrm{ppm}$, at different growth periods of $5,10,15,20,25$ and 30 days. Results revealed that azolla can grow healthy with the accumulation of these metals. The highest fresh and dry weights of azolla were observed after 30 days at $2.0 \mathrm{ppm}$ of $\mathrm{Cu}^{+2}$. These values were significantly higher than those for $\mathrm{Pb}^{+2}$ and $\mathrm{Cd}^{+2}$ at 1.0 and $0.5 \mathrm{ppm}$, respectively. Also, azolla fronds exerted higher nitrogenase activity when grown in culture medium without heavy metals, or supplemented with 1.5, 1.5 and $0.5 \mathrm{ppm}$ of $\mathrm{Pb}^{+2}, \mathrm{Cd}^{+2}$ and $\mathrm{Cu}^{+2}$, respectively. The highest records of nitrogen uptake were obtained, in the presence of $\mathrm{Cu}^{+2}$ $(2.0 \mathrm{ppm})$ treatment, while phosphorus uptake increased with increasing the concentrations of $\mathrm{Pb}^{+2}$ and $\mathrm{Cu}^{+2}$ from $0.5 \mathrm{ppm}$ to 2.0 $\mathrm{ppm}$. On the other hand, phosphorus uptake decreased with increasing the concentrations of $\mathrm{Cd}^{+2}$ from 0.5 to $2.0 \mathrm{ppm}$. Potassium uptake in response to different $\mathrm{Cd}^{+2}$ concentrations was lower than the other treatments including the control, from 5 to 30 days of growth periods. The greatest contents of $\mathrm{Pb}^{+2}, \mathrm{Cd}^{+2}$ and $\mathrm{Cu}^{+2}$ were observed in azolla fronds grown in presence of $2.0 \mathrm{ppm}$ of any of these elements and collected after 30 days. $\mathrm{Pb}^{+2}$ uptakes were higher at the concentration of $2.0 \mathrm{ppm}$ compared with other concentrations of $\mathrm{Cd}^{+2}$ and $\mathrm{Cu}^{+2}$. Thus, Azolla pinnata showed tolerance to the tested heavy metals at concentration up to $1 \mathrm{mg} / \mathrm{l}$ that supposed to pollute the medium. Therefore, azolla can serve as a phytoremdiation agent in the heavy metal polluted habitats.
\end{abstract}

\section{INTRODUCTION}

Recently the environment is heavily polluted by various toxic metals, which create danger problems for all living organisms. These metals are retarding farming efficiency and destructing the health of both plants and animals (Varsha et al., 2010).

The capability for removing toxic heavy metals and trace elements from contaminated soils and water by using some plants is a process referred to as phytoremediation. Several terrestrial plants that have been identified in the last two decades as highly effective for absorbing and accumulating various toxic elements are evaluated for their role in the phytoremediation of soils polluted with toxic elements 
(Tang et al., 2001). Phytoremediation is a new approach that offers more ecological benefits and a cost efficient alternative. It is a cheap method but it requires technical strategy; expert project designers with field experience that choose the proper species and cultivars for particular metals and regions. During various researches, the main focus is to understand the physiological mechanisms of metal absorption, transportation and assimilation; but little is known regarding the genetic basis of hyper accumulation (Pollard et al., 2002).

Heavy metal pollutant tolerance of azolla may be due to uptake of the metals into cell wall and vacuoles through an intensive carrier transporting system as well as evolution of specific metal resistance enzyme and alteration of cellular metabolites (Forstner and Wittmann, 1981).

The objective of the current work is to investigate the capability of Azolla pinnata to accumulat lead $\left(\mathrm{Pb}^{+2}\right)$ cadmium $\left(\mathrm{Cd}^{+2}\right)$ and copper $\left(\mathrm{Cu}^{+2}\right)$ in an enriched metal solution.

\section{MATERIALS AND METHODS}

\section{Azolla strain and inocula}

Azolla pinnata, used in the present study was kindly provided by Soils, Water and Environ. Res. Inst. (SWERI), Agric. Res. Center (ARC) Giza. The collected azolla fronds were sterilized with mercuric chloride $(0.1 \%)$ for $30 \mathrm{sec}$. according to Vandna and Ashwani (1999) and washed by sterilized water several times. Hundred grams of fresh azolla fronds were plotted between two sheets of tissue paper and then air dried for 30 minutes, afterwards it was used to put in plastic dishes with $40 \mathrm{~cm}$ in diameter and $9 \mathrm{~cm}$ in depth containing the enriched metal solution of Yoshida medium (Yoshida et al., 1976). Also these. Azolla fronds represent the standard inoculum throughout the experiment. Azolla inoculum was used at a rate of $100 \mathrm{gm} / \mathrm{m}^{2}$

Yoshida medium was supplemented with different concentrations, $(0.0,0.5$, $1.0,1.5$, and $2.0 \mathrm{ppm}$ ) of either $\mathrm{Pb}^{+2}, \mathrm{Cd}^{+2}$ or $\mathrm{Cu}^{+2}$ in the form of $\mathrm{PbSO}_{4}, \mathrm{CdSO}_{4}$ and $\mathrm{CuSO}_{4}$. Five replicates were prepared for each treatment. The azolla fronds in plastic dishes at the rate of $100 \mathrm{~g} / \mathrm{m}^{2}$ were grown under greenhouse conditions. The evaporated water was compensated by adding deionized water when needed. Developed azolla growth was periodically sampled at $0.0,5,10,15,20,25$ and 30 days to determine fresh and dry weights (El-Shahat, 1997), nitrogenase activity (Hardy et al., 1973) and total nitrogen, phosphorus, potassium (Black et al., 1965), and the accumulation of $\mathrm{Pb}^{+2}, \mathrm{Cd}^{+2}$ and $\mathrm{Cu}^{+2}$ were determined on dry weight basis by 
using atomic absorption according to Jackson (1976).Data were statisticaly analyzed for least significant differences at P 0.05 as described by Gomez and Gomez (1984).

\section{RESULTS and DISCUSSION}

\section{Fresh weight}

Results revealed a significant increase in fresh weights (Table 1) with increasing the growth period up to 30 days. On the contrary, increasing the concentrations up to $2.0 \mathrm{ppm}$ of $\mathrm{Pb}^{+2}$ and $\mathrm{Cd}^{+2}$ decreased the fresh weights of Azolla. The highest Azolla fresh weight of $8049.33 \mathrm{gm} / \mathrm{m}^{2}$ was due to exposing azolla to 2

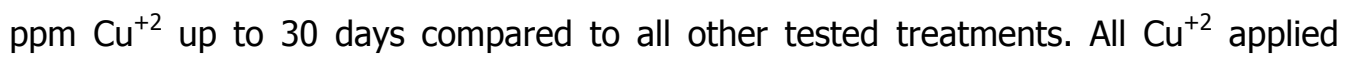
concentrations increased Azolla fresh weight to be significantly higher than those recorded by the control treatment. Rauf et al. (2009) reported that copper $\left(\mathrm{Cu}^{+2}\right)$ is an essential plant micronutrient and often occurs in high concentrations in the aquatic ecosystems. In addition, $\mathrm{Cu}$ has spread contamination level due to its use as a mineral pesticide in agriculture (Ahmad et al., 2008). Khosravi et al. (2005) found that the presence of $\mathrm{Pb}^{+2}, \mathrm{Cd}^{+2}, \mathrm{Ni}$ and $\mathrm{Zn}$ in nutrient solution of Azolla caused approximately $25,42,31$ and $17 \%$ inhibition of biomass growth, respectively, compared with that of Azolla in heavy metals lacking medium.

Generally, the effect of $\mathrm{Pb}^{+2}$ and $\mathrm{Cd}^{+2}$ was more or less harmful rather than $\mathrm{Cu}^{+2}$ to azolla growth.

\section{Dry weight}

The obtained results showed a significant increase in dry weight of Azolla (Table 2) with increasing growth periods up to 30 days. On the contrary, different concentrations of $\mathrm{Pb}^{+2}$ and $\mathrm{Cd}^{+2}$ decreased significantly Azolla dry weight compared to control. These decreases were noticed along with increasing metal concentration from 1 up to $2 \mathrm{ppm}$ to both $\mathrm{Pb}^{+2}$ and $\mathrm{Cd}^{+2}$. Regarding $\mathrm{Cu}^{+2}$ effect on Azolla dry weight, results revealed that Azolla dry weight responded positively to the increase of $\mathrm{Cu}^{+2}$ concentration from 1 to $2 \mathrm{ppm}\left(123.38 \mathrm{gm} / \mathrm{m}^{2}\right)$. The highest Azolla dry weight of $340.04 \mathrm{gm} / \mathrm{m}^{2}$ was from $2 \mathrm{ppm} \mathrm{Cu}{ }^{+2}$ treatment at 30 days compared to the other tested treatments. Wang and Chen (2006) suggested that metal ions are adsorbed first to the cell surface by interactions with metal-functional groups as carboxyl, phosphate, hydroxyl, amino, sulphur, sulphide group...etc., and then penetrate the cell membrane and enter into the cell. On the other hand, all $\mathrm{Cu}^{+2}$ applied concentrations at all incubation periods increased azolla dry weight compared to control treatment. 
Table 1. 
Table 2. 


\section{Nitrogenase activity}

The different applied metal concentrations exhibited different effects on nitrogenase activity of $A$. pinnata (Table 3 ). However, the highest values of nitrogenase activity were 21.94, 18.42 and $14.60 \mu \mathrm{mol} \mathrm{C}_{2} \mathrm{H}_{4} / \mathrm{gm}$ dry wt/hr at concentrations of $1.5,1.5$ and $0.5 \mathrm{ppm}$ of $\mathrm{Pb}^{+2}, \mathrm{Cd}^{+2}$ and $\mathrm{Cu}^{+2}$ at 25,20 and 25 days of growth, respectively. These findings were observed by El-Berashi (2008) who reported that the highest value records of nitrogenase activity were 21.80, 19.83, 13.53 and $19.42 \mu$ mole $\mathrm{C}_{2} \mathrm{H}_{4} / \mathrm{gm}$ dry wt./hr with concentrations of $1.0,1.0,5.0$ and $3.0 \mathrm{ppm}$ of $\mathrm{Pb}, \mathrm{Zn}, \mathrm{Cu}$ and $\mathrm{Mo}$ after 2, 5, 5 and 10 days of growth periods, respectively. The authoress also found that $\mathrm{N}$-uptake of $A$. pinnata in presence of $\mathrm{Pb}$, $\mathrm{Zn}, \mathrm{Cu}$ and Mo with respective concentrations of 4, 4, 2 and 5 ppm were 4864.8, $7709.9,6079.2$ and $2174.5 \mathrm{mg} / \mathrm{m}^{2}$ at $25,25,25$ and 20 days growth period, respectively.

\section{Nitrogen uptake}

The mean values of $\mathrm{N}$-uptake (Table 4 ) increased with prolonged growth periods. Different concentrations of $\mathrm{Pb}^{+2}$ and $\mathrm{Cd}^{+2}$ tended to decreased significantly the N-uptake compared to control treatment. These decreases were noticed along with increasing metal concentration from 1 up to $2 \mathrm{ppm}$. In respect to $\mathrm{Pb}^{+2}$ and $\mathrm{Cd}^{+2}$. Results of $\mathrm{Cu}^{+2}$ effects on $\mathrm{N}$-uptake by azolla fronds revealed that it was positively responded to the increase of $\mathrm{Cu}^{+2}$ concentrations up to $2 \mathrm{ppm}$. The highest values of nitrogen uptake were obtained with 2.0 and $0.0 \mathrm{ppm} \mathrm{Cu}^{+2}, 0.5 \mathrm{ppm} \mathrm{Pb}^{+2,}$ and 0.5 ppm $\mathrm{Cd}^{+2}$ given 9572.31, 8721.32, 7174.12 and $7088.41 \mathrm{mg} / \mathrm{m}^{2}$ respectively, at 30 days of growth periods. 
Table 3. 
Table 4. 


\section{Phosphorus uptake}

P-uptake (Table 5) increased with increasing the growth periods up to 30 days with $\mathrm{Pb}^{+2}, \mathrm{Cd}^{+2}$ and $\mathrm{Cu}^{+2}$, respectively. Maximum uptake of phosphorus by azolla fronds was obtained after 30 dayes of growth at $2.0 \mathrm{ppm}$ of $\mathrm{Pb}^{+2}\left(742.67 \mathrm{mg} / \mathrm{m}^{2}\right)$ and at $2.0 \mathrm{ppm}$ of $\mathrm{Cu}^{+2}\left(2943.42 \mathrm{mg} / \mathrm{m}^{2}\right)$ while P-uptake showed a lower value $\left(1595.80 \mathrm{mg} / \mathrm{m}^{2}\right)$ at $2.0 \mathrm{ppm}$ after 30 days of growth period.

\section{Potassium uptake}

Data presented in Table 6 showed an increase of K-uptake with increasing the growth period up to 30 days in the presence of any of $\mathrm{Pb}^{+2,} \mathrm{Cd}^{+2}$ and $\mathrm{Cu}^{+2}$. On the other hand, different concentrations of $\mathrm{Pb}^{+2}, \mathrm{Cd}^{+2}$ and $\mathrm{Cu}^{+2}$ increased significantly the values of $\mathrm{K}$ uptake. The application of $2.0 \mathrm{ppm} \mathrm{Pb}^{+2}$ or $\mathrm{Cu}^{+2}$ to the growth medium increased significantly K-uptake to higher values $\left(6361.60\right.$ and $6229.06 \mathrm{mg} / \mathrm{m}^{2}$ for $\mathrm{Pb}^{+2}$ and $\mathrm{Cu}^{+2}$, respectively) at 30 days of growth periods. In the $\mathrm{Cd}^{+2}$ treatments, $\mathrm{K}-$ uptake at 30 days growth period was the lower compared with $\mathrm{pb}^{+2}$ and $\mathrm{Cu}^{+2}$ values. Costa et al. (1999) stated that the biomass analysis of azolla showed that nitrogen, phosphorous, potassium and organic content could favor the use azolla as biofertilizer especially when it is growing in domestic waste waters. 
Table 5. 
Table 6. 


\section{Heavy metals accumulation}

Results revealed that the $\mathrm{Pb}^{+2}, \mathrm{Cd}^{+2}$ and $\mathrm{Cu}^{+2}$ accumulated in azolla fronds (Table 7) after 30 days of growth period were highly significant compared with the control treatment. The highest accumulations of $\mathrm{Pb}^{+2}, \mathrm{Cd}^{+2}$ and $\mathrm{Cu}^{+2}$ were 270.11, 255.20 and $209.50 \mathrm{mg} / \mathrm{m}^{2}$, respectively, at the concentration of $2.0 \mathrm{ppm}$ at 30 day growth period. Taghi ganji et al. (2005) concluded that, the removal of heavy metal ions $\left(\mathrm{Pb}^{+2}, \mathrm{Cd}^{+2}, \mathrm{Cu}^{+2}\right.$ and $\left.\mathrm{Zn}^{+2}\right)$ throughout azolla fronds depends on the treatment conditions of biomass and the biosorption process. Other studies showed that the contents of metals determined in the solution medium decreased whereas accumulation of the metals inside Azolla tissues was increased (Stepniewska et al., 2005). On the other hand, the aquatic fern azolla has been reported to accumulate high concentrations of heavy metals and metalloids (3-4 $\left.\mathrm{mgl}^{-1}\right)$ from aqueous media (Rai and Tripathi, 2009). Sastry et al. (2005) reported that, the content of $\mathrm{Pb}^{+2}$ was up to $416 \mathrm{mg} / \mathrm{kg}$ dry weight and cadmium up to $259 \mathrm{mg} \mathrm{Cd} / 2 / \mathrm{kg}$ dry weight of Azolla. They suggested that, Lemna minor and A. Pinnata, can take up copper and decrease its concentration in the medium, therefore, they can effectively used for the treatment of waste water by developing the appropriate technology. 
Table 7. 


\section{REFERENCES}

1. Ahmad, M. S. A., M. Hussain, S. Ijaz and A. K. Alvi. 2008. Photosynthetic performance of two Mung bean (Vigna radiate) cultivars under lead and copper stress. Int. J. Agric. Biol., 10: 167-172.

2. Black, C. A., D. D., Evans, L. E., Ensmingrers, J. L., White, F. E., Clark and R. C. Dinouer. 1965. Methods of Soil Annalysis 11. Chemical and Microbiological Properties. Amer. Soc. Agron. Inc. Madison, Wisconsin, U.S.A. pp.1149-1176.

3. Costa, M. L., M. C. Sntos and F. Carrapico 1999. Biomass characterization of Azolla filiculoides grown in natural ecosystems waster. Hydrobiologia 415: 323327.

4. Dai, P. L., T. Z. Xiong , Y. Huang and L. I. Jing. 2006. Cadmium induced changes in pigments, total phenolic, and phenylanine Ammonia Iyase activity in fronds of Azolla imbericata, wlles Periodicals. Inc. Environ . Toxicol., 21: 505-512.

5. El- Berashi Nadia, M. Y. 2008. Impacts of azolla in increasing rice production and Reducing environmental pollution . In ph.D. Ain Shams Univ. pp 110-157.

6. El- Shahat, R. M. 1997. Prospects of azolla as biofertilizer in Egypt. Ph, $D$, Thesis In Agricultural Microbiology, Department of Agric. Botany, Faculty of Agriculture, Ain Shams University, Cairo, Egypt.

7. Forstner, U. and G. T. W. Wittmann. 1981. Metal Pollution in the Aquatic Environment.Springer- Verlag. 9: 102-116

8. Gomez, K. A. and A. A. Gomez. 1984. Statistical Procedures for Agricultural Research, ( $2^{\text {nd }}$ ed), pp. 20-29 \& 359-387.

9. Hardy, R. W. E., R. C. Burns and R. D. Holsten. 1973. Application of the acetylene- ethylene assay for measerment of nitrogn fixation. Soil Biol. Biochem., 5: 47-81.

10. Jackson, M. L. 1976. "Soil Chemical Analysis", Prentice-Hall Englewood Cliffs, New Jersey. U.S.A.

11. Khosravi, M., M. Taghi and Gonji R. Rakhshaee. 2005. Toxic effect of pb, Cd, Ni and $\mathrm{Zn}$ on Azolla hiliculoties in the international Anzali wetland. Int. J. of Environ . Sci. and Technology 2(1): 35-40.

12. Pollard A. J., K. D., Powell, F. A. Harper and J. A. C. Smith. 2002. The genetic basis of metal hyperaccumulation in plants. Crit. Rev. Plant Sci., 21: 539-566.

13. Rai, P. K. and B. D. Tripathi. 2009. Comparative assessment of Azolla pinnata and Vallisneria spiralis in $\mathrm{Hg}$ removal from G.B. plant sagar of singrauli industrial region, India Environ.Monit Assess., 148: 75-84. 
14. Rauf, A. M., Javed, M. Vbaidullah and S. Abdulah. 2009. Assessment of heavy metals in sediments of the river Ravi, Pakistan. Iner. J. Agric. Biol., 11: 197-200.

15. Sastry, K. V. K. Krishan and N. K. Chadha. 2005. Biororemediation of heavy metal pollution by lemna minor and Azolla pinnata. Environ. \& Ecol., 23(3): 587592.

16. Stepniewska, Z., R. P. Bennicell and T. I. Balakhae. 2005. Potential of A. Carolinana for the removal $\mathrm{pb}$ and $\mathrm{Cd}$ from wastewater . Int . Agrophysics 19: 251-255.

17. Taghi -ganji, M., M. Khosravi and R. Rakhshaee. 2005. Biosorption of $\mathrm{Pb}^{+2}, \mathrm{Cd}^{+2}$, $\mathrm{Cu}^{+2}$ and $\mathrm{Zn}^{+2}$ from the wastewater by treated Azolla filiculoides with $\mathrm{H}_{2} \mathrm{O}_{2} / \mathrm{Mg}$ $\mathrm{Cl}_{2}$. Intr. J. Environ. Sci. Techno., .1 (4): 265-271.

18. Tang, S., B. M. Wilke, and R. R. Brooks. 2001. Heavy-metal uptake by . metaltolerant Elsholtzia haichowensis and Commelina communis from China.Commun. Soil Sci. Plant Anal., 32: 895-905.

19. Vandna , R. and K. R. Ashwani. 1999. Growth behavior of Azolla pinnata at various salinity levels and induction of high salt tolerance. Plant and Soil. 206: 7984.

20. Varsha, M., N. Madaan, and A. Mudgal. 2010. Heavy metals in plants: phytoremediation : plants used to remediate heavy metal pollution. Agric. and Biol. J. of North America Issn Online. 2151-7525.

21. Wang, J. and C. Chen. 2006. Biosorption of heavy metals by Saccharomyces cerevisiae: A Review. Biotechnol. Adv., 24:427-451.

22. Yoshida, S., D. A. Forno, J. H. Corck and K. A. Gomez. 1976. Laboratory Manual for Physiology Studies of Rice . Laguna, pp,61-65. International Rice Res Inst. Los Banos, Manila, Philippines. 


\section{المعالجة الحيوية للتلوث بالعناصر الثقيله باستخدام نبات الازولا}

\section{عزه احمد محمد عبد العال 1 إلهام محمد محمود عارف1 حنان احمد محمود2}

ا ـ معرد بحوث الأراضى و المباهو البئية (قسم بحوث الميكروبيولوجيا الزراعي مة) ، مركز

$$
\text { البحوث الزراعتي. }
$$

r . معهُ بحوث الانتاج الحبوانسى (قسم بحوث استخدام الدخلفات )، مركز البحوث النزراعية ،

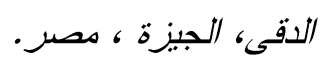

\section{استخدام النباتات من أكثر التقنياتِ الجديدةٍ الوَاعِدِة لمعالجةِ المياه الملوثة. فى هذه الدراسه}

تم استخدام Azolla pinnata سرخس مائى قادر على امتصاص بعض العناصر الثقيله فى بيئه يوشيدا

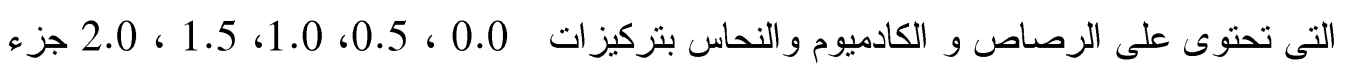
فى المليون. واختبرت Azolla pinnata على قابليتها لامتصاص هذة العناصر على فترات مختلفة 5 ، 5 ،

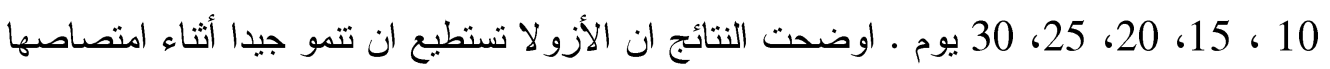

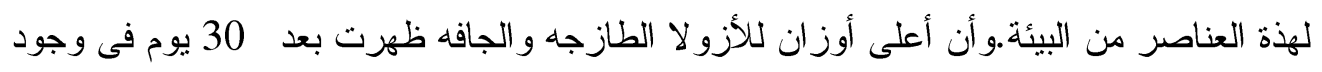

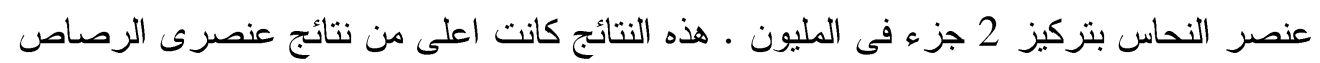

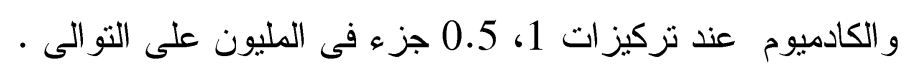

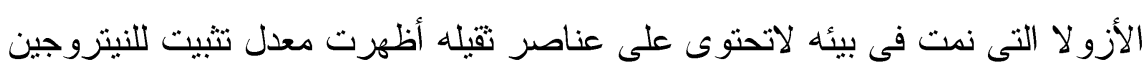

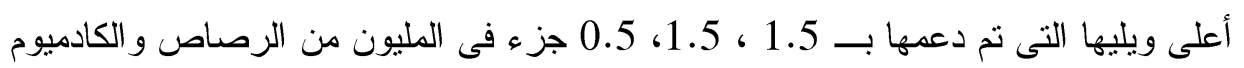

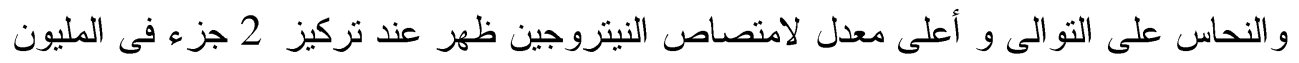
للنحاس و الممتص من الفوسفور يزداد بزياده تركيز الرصاص و النحاس من 0.5 جزء النهى في المليون الى 2.00 جزء فى المليون ـ على الجانب الاخر الممنص من الفوسفور يقل بزياده تركيز الكادميوم من 0.5 الى 2 جزء فى المليون و الممتص من البوتاسيوم فى التركيز ات المختلفه من الكادميوم كان

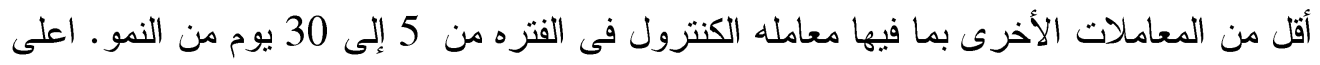

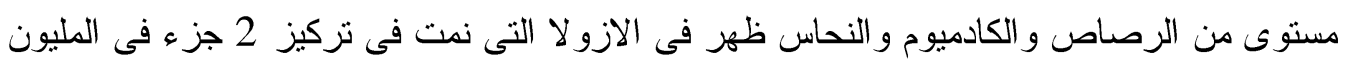

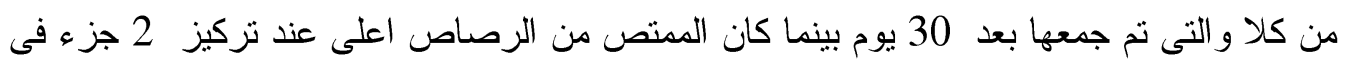

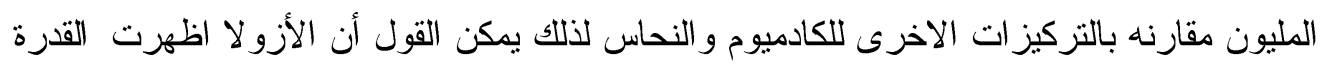

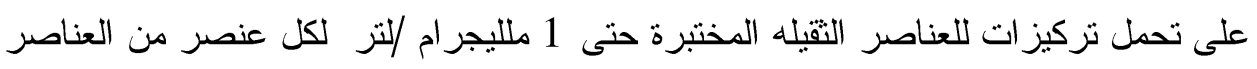
الملوثه وكذلك تنقية المياه من بعض العناصر التقيلة. 